\title{
CHARACTERIZATION OF DROUGHT EVOLUTION USING THE STANDARDIZED PRECIPITATION INDEX (SPI) IN THREE AGRO-CLIMATIC ZONES OF SETTAT PROVINCE, MOROCCO
}

\author{
Mohamed Amine El Mzouri' ${ }^{1}$, Karima Samir ${ }^{2}$, Mohamed Chlaida ${ }^{2}$
}

\section{and El Houssine El Mzouri ${ }^{3}$}

${ }^{1}$ Department of Biology, PhD student, Faculty of Sciences Ben M'sik, Hassan $2^{\text {nd }}$ University. Casablanca, Morocco. E-mail: elmzourimohamedamine@gmail.com

${ }^{2}$ Department of Biology, Professor, Faculty of Sciences Ben M'sik, Hassan $2^{\text {nd }}$ University. Casablanca, Morocco.

3Department of Agronomy, Senior scientist adviser for Al Moutmir Initiative-OCP Group Faculty of Agriculture, Mohamed $6^{\text {th }}$ University Polytechnic. Benguerir, Morocco.

Cite this article:

El Mzouri M.A., Samir K., Chlaida M., El Mzouri E. (2021), Characterization of Drought Evolution using the Standardized Precipitation Index (SPI) in Three AgroClimatic Zones of Settat Province, Morocco. African Journal of Environment and Natural Science Research 4(4), 109-122. DOI: 10.52589/AJENSRI3Y1BRCV.

\section{Manuscript History}

Received: 20 Oct 2021

Accepted: 9 Nov 2021

Published: 27 Nov 2021

Copyright ()$^{2} 2020$ The Author(s). This is an Open Access article distributed under the terms of Creative Commons AttributionNonCommercial-NoDerivatives 4.0 International (CC BY-NC-ND $4.0)$, which permits anyone to share, use, reproduce and redistribute in any medium, provided the original author and source are credited.
ABSTRACT: Morocco has been experiencing significant climatic disturbances in recent decades. The climate change issue arises mainly in terms of water deficits induced by the decrease in rainfall received and the increase in temperature. The objective of this study is to characterize the drought temporal and spatial distribution and severity within local agro-climatic zones of Settat Province. The study area extends over a distance of 85 $\mathrm{km}$ from North to South and concerns three agro-climatic zones. The Standardized Precipitation Index was used for drought analysis and characterization in the three zones for 107 years of rainfall data. Results show that numbers of normal average years are declining, dry years are increasing and humid years are declining in three zones. However, the SPI changes over time are not similar for the three zones, that is, the rainfall deficit is taking place more in the "Favorable Rain-fed" zone and to a low degree in the "Intermediate Rain-fed" but not in the "Less Favorable" zone.

KEYWORDS: Morocco, Climate Change, Spi, Drought, Agroclimatic Zones, Settat Province. 


\section{INTRODUCTION}

Morocco, located in the North West of Africa between the Atlantic Ocean, the Mediterranean Sea and the Great Sahara, has experienced significant climatic disturbances in recent decades (IPCC, 2013). Several studies have shown the inter- and intra-annual variability of rainfall with a rather remarkable downward trend in rainfall over the last sixty years (Born et al., 2008; Agoumi \& Debbarh, 2006), increasingly frequent droughts (Mokssit, 2012; Sebbar et al., 2013), more frequent sporadic torrential rains by locality (Ait Bella \& Samih, 2020; Sebbar, 2013) and a remarkable rise in temperature (El Jihad et al., 2014; Sebbar, 2012). All these studies agree that climate change is taking place in Morocco especially in the semi-arid, humid and sub-humid areas (Sebbar et al., 2011; Mokssit, 2012; Driouech, 2009a).

In Morocco, the issue of climate change arises mainly in terms of water deficits induced by the quantitative decrease in normal rainfall received, the resurgence of drought periods, the increase in losses by evaporation under the effect of the gradual rise in temperatures, and the resurgence of extreme climatic hazards (Zamrane, 2018; Boubekri et al., 2019). These aspects not only affect agricultural productivity but they also affect the cropping systems and farming practices such as cropping and livestock management, the use of inputs and the allocation of resources (Zinyengere et al., 2015). The seasonal and annual rainfall trend has been decreasing in the semi-arid rain-fed area since 1980 (Sebbar, 2013; Ait Bella \& Samih, 2020). The study of the climatic characteristics evolution using the Standardized Precipitation Index (SPI) method will allow the characterization of the spatial and temporal variability of drought in a small-scale territory (Settat province) that represents the Chaouia plain cereal belt.

The objective of this study is to characterize the drought temporal and spatial distribution severity within homogeneous agro-climatic zones in order to better target later the adaptation strategies of the existing rain-fed farming systems in Settat Province.

\section{LITERATURE}

Drought is one of the natural disasters that have deeply marked the lives of populations throughout the ages. It does not have a universal definition; there are as many definitions of drought as there is water use: drought is indeed a lack of water availability compared to a situation considered normal for a given period, a specific region and/or specific uses (Ait Bella $\&$ Samih, 2020). The general term "drought" covers different concepts. We will distinguish a "punctual" lack of water (drought) from a structural water deficit (aridity). Aridity is a systematic deficit of rainfall. In so-called arid regions, precipitation is less than the potential evapotranspiration. In contrast, drought defines an unsystematic rainfall deficit and it is therefore characterized by the intensity of its deviation from an average or normal rainfall value (Jones, 1992).

Different quantitative elements characterize droughts: the duration (intermittent or prolonged drought), the occurrence period, the geographical extension, the establishment dynamics (sudden or progressive) and the time of occurrence in relation to the crop cycle. Therefore, when considering crops of our study area, a drought corresponds to a deficit of water in the soil and/or in the air, resulting in decrease of the entire plant absorbed water quantity in comparison with the amount of water evaporated. 
The Mediterranean basin is considered by the latest IPCC report to be a climatic "hot spot" (IPCC, 2013) that is sensitive to climate change effects. This region, known for its strong interannual rainfall variability due to the vulnerable geo-climatic position, has generated a lot of research on the climate characterization and on water availability in this part of the globe (Meddi \& Meddi, 2009).

Morocco, one of the countries on the southern Mediterranean shore, has not escaped global climate change (Sebbar et al., 2011). As in all the world semi-arid and arid regions, highly variable annual and seasonal rainfalls characterize the climatic trends of this country. In terms of recent evolution, precipitation has recorded a general downward trend, disparate over time and space, and highly fluctuating. Maximum winter and summer temperatures follow an exponential curve (Driouech, 2009b). The majority of climatic stations in Morocco report a downward trend in annual and seasonal rainfall (Sebbar et al., 2012). According to the same investigators, the change and disruption of the annual rainfall regime during the 1970s previously demonstrated applies to the seasonal scale. Thus, they reported a decline in the middle and the end of the rainy season (winter and spring) and a slight increase in fall precipitation over the entire central region of Morocco. This downward trend in rainfall has been associated with the decrease in the frequency of disturbances coming from the NorthWest, and that often affects the central region of Morocco during winter and spring seasons.

During the 1961 to 2004 period, the frequency and severity of droughts increased considerably, with a strong trend towards a decrease in the number of wet years and a more remarkable increase in the number of dry years (Ait Bella \& Samih, 2020; Sebbar, 2013). They observed an increase in the duration of consecutive days without rain during the rainy season (September-April) that reached more than 15 days, and a decrease in precipitation of around $23 \mathrm{~mm}$ on average. This decrease reached $38 \mathrm{~mm}$ in the Northwest region, which is the equivalent of a third of the normal rainfall (El Ouali, 2010).

The projections established by the National Meteorological Directorate predict an increase in average summer temperature of around $2{ }^{\circ} \mathrm{C}$ to $6{ }^{\circ} \mathrm{C}$, and an average decrease of $20 \%$ in precipitation by the end of the century (Mokssit, 2012; Sebbar et al., 2013; Driouech et al. 2010). In future climate scenarios, a decrease in precipitation is expected and an increase in extreme drought conditions in Morocco. The predicted drop in rainfall will affect water resources, especially surface water that feeds the largest dams and reservoirs.

Meteorologists and climatologists use many indices for drought characterization all over the world, ranging from the simplest, such as percentage of normal precipitation or precipitation percentiles, to the more complex ones. In the USA, scholars have realized that an index should be simple, easy to calculate, and statistically relevant and meaningful. Of all the developed drought indices, the Standardized Precipitation Index (SPI) (McKee et al., 1993) is the most popular in characterizing meteorological drought. The SPI was developed in order to characterize the precipitation deficits for a given period and to reflect the impact of drought on different water resources availability.

This index is widely used throughout the world for drought analysis, especially meteorological ones (Pashiardis \& Michaelides, 2008; Tirandaz \& Eslami, 2012; Jacobi et al., 2013; Alahiane et al., 2018). The standardized precipitation index has advantages in terms of statistical consistency and the ability to describe-both short term and long term-drought impacts 
across different time scales. The probabilistic nature of this index allows it to be comparable between different sites (Mirabbasi et al., 2013).

\section{METHODOLOGY}

\section{The Study Area}

The Province of Settat, located in the center of the Kingdom of Morocco, covers approximately $7,220 \mathrm{~km}^{2}$ that represents $35 \%$ of the area of the Casa-Settat region. It covers the southern part of the Chaouia Atlantic plain and all of Beni Mesquines territories that are known for their small grains and livestock production. The climate of Settat Province is Mediterranean semiarid type with oceanic influence with two distinct seasons: a cool rainy season (October to April) and a hot dry season (May to September). The average monthly temperatures vary between $12{ }^{\circ} \mathrm{C}$ and $29^{\circ} \mathrm{C}$. December-January are the coldest months with minima reaching 5 ${ }^{\circ} \mathrm{C}$, and July-August are the hottest months with maxima that exceed $38^{\circ} \mathrm{C}$. The study area is dominated by three types of wind: wind from the West which is cool and humid and prevails during winter, wind from the South-West which is temperate and humid in winter but hot and dry in summer, and wind from East (Sirocco) which is cold and dry in winter but hot and dry in summer.

The study area extends over a distance of $85 \mathrm{~km}$ from North to South and concerns three agroclimatic zones of Settat Province (Fig. 1):

- The "Favorable Rain-fed" agro-climatic zone hereinafter referred to as "Settat Zone": This zone, located in the northern part of the province, is characterized by a favorable climate (300 to $340 \mathrm{~mm} / \mathrm{year}$ ) with an oceanic influence on humidity and temperatures. According to Emberger's (1930) climatic classification, with Q2 = 47.7, this zone belongs to the Medium Semi-Arid bioclimatic class with temperate winters.

- The "Intermediate Rain-fed" agro-climatic zone hereinafter referred to as "Guisser Zone": This zone, located south of the previous zone, is characterized by a less favorable climate (240 to $280 \mathrm{~mm} / \mathrm{year}$ ) with a more continental and a less oceanic influence on humidity and temperature than the previous zone. With an Emberger quotient of Q2 $=34$, this zone belongs to the Low Semi-Arid bioclimatic class with temperate winters.

- The "Less Favorable Rain-fed" agro-climatic zone hereinafter referred to as "El Brouj Zone": This zone, located in the south of the province, is characterized by an unfavorable climate (180 to $240 \mathrm{~mm} / \mathrm{year}$ ) with a greater arid continental influence. Emberger's quotient has a value of Q2 $=28.8$; therefore this zone belongs to the Upper Arid bioclimatic class with temperate winters. 


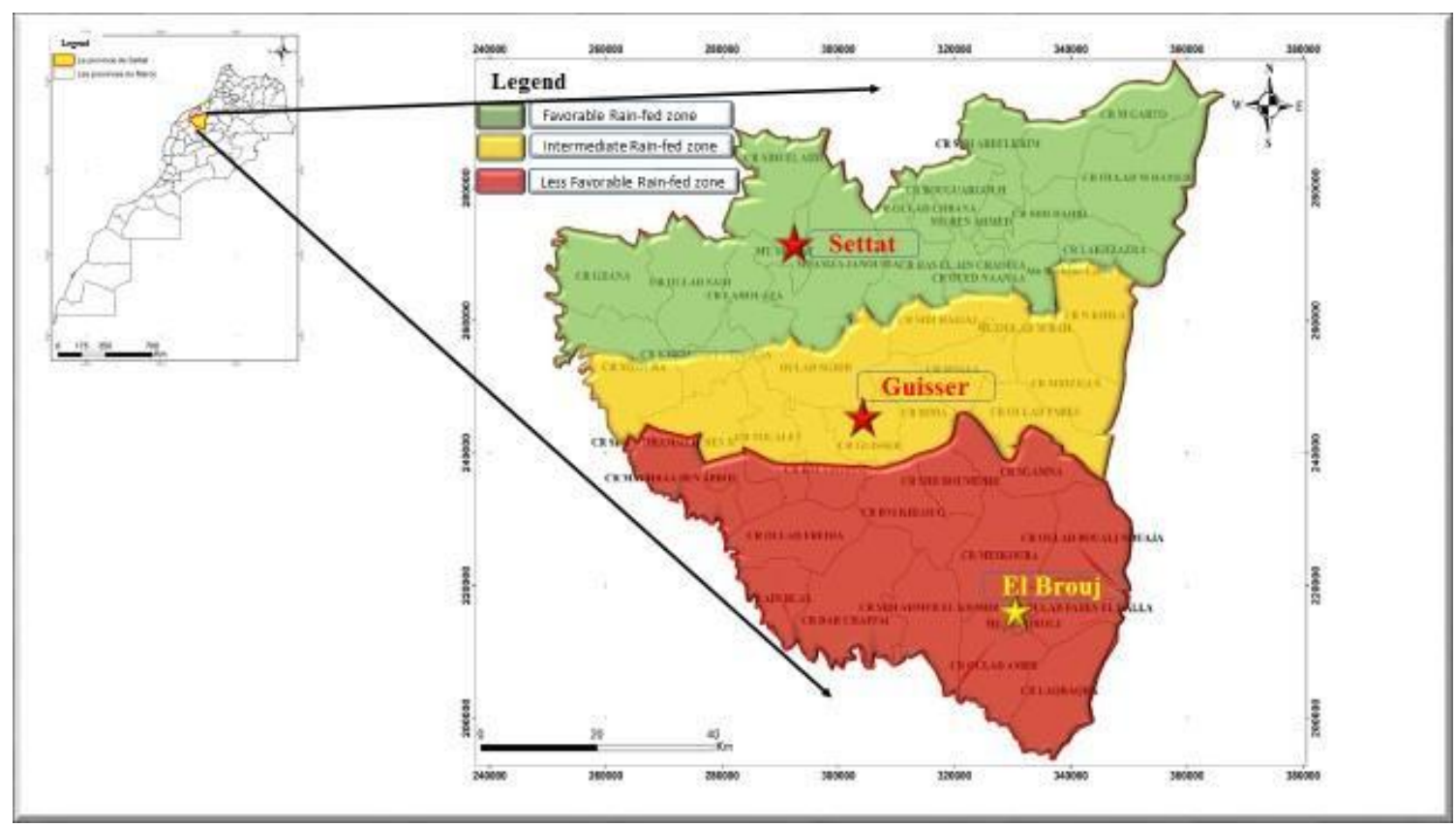

Figure 1: Map of the three agro-climatic zones of Settat Province, Morocco.

\section{Climatic Data Used}

The problems of climatological measurements are crucial in any climatological study. When measurements of climate elements are available, they often suffer from failures such as station representativeness, gaps, data entry errors, and erroneous values or homogeneity problems. Along with these obstacles, there is also that of the availability of updated series. The climatic characteristics of the sites (variability, trends, etc.) are highlighted using statistical tools and specific software packages developed for this purpose. The reliability of the results depends on the quality of the climatic series which are used (length, homogeneity, geographical position, gaps, etc.).

The climatic data (rainfall, and minimum and maximum temperatures) used in this study are those of the:

- INRA (National Institute for Agricultural Research) database provided by the stations in Sidi El Aydi and Jemâa Riah, in addition to the national database available in the agro climatology laboratory at INRA of Settat,

- DMN (National Meteorogical Directorate) stations in Ai Nzagh and El Massira Dam,

- Ministry of Agriculture stations available at the Agricultural Extension centers of Settat, Sidi El Aydi Oulad Saïd, Guisser, Ben Ahmed, Khémis Sidi Mohamed Ben Rahal, El Brouj, and Oulad Gnaou (ORMVA Tadla). 


\section{The Standardized Precipitation Index (SPI): A Tool for Characterizing Droughts.}

The Standardized Precipitation Index (SPI) is widely used around the World for drought analysis and characterization (Tirandaz \& Eslami, 2012). The SPI has advantages in terms of statistical consistency and the ability to describe - both short term and long term - the impacts of drought across different time scales. The probabilistic nature of this index allows it to be comparable between different sites (Mirabbasi et al., 2013). This index is considered at the same time simple and robust. It is based on rainfall data adopted by the World Meteorological Organization (WMO) in 2009, as a global instrument for measuring meteorological droughts. It allows the check of both wet and dry period cycles. The mathematical formula for SPI is as follows:

$$
\mathrm{SPI}=(\mathrm{Pi}-\mathrm{Pm}) / \sigma 121
$$

where $\mathrm{Pi}=$ the total annual rainfall of the $\mathrm{i}$ year; $\mathrm{Pm}=$ the average rainfall et $\sigma:$ Standard deviation.

\section{RESULTS}

\section{Drought Evolution}

\section{"Favorable Rain-fed" Agro-climatic Zone or "Settat Zone"}

The calculation of the standardized precipitation index (SPI) for the 2014-2020 rainfall series for the Settat zone shows high variability with a downward trend of this index (Fig. 2). Indeed, at the start of this rainfall series, the SPI was rather positive with few dry years while towards its end, it was negative indicating the high frequency of dry years during recent years.

The overall analysis shows that the majority of years (71 years or $66 \%$ ) had indices close to normal $(-0.99<$ SPI < 0.99) (Table 1$)$. Moderately humid to extremely humid years $(1<\mathrm{SPI}<$ +2 ) represented $21 \%$ or 22 years) over the entire series, while moderately dry to extremely dry years $(-2<$ SPI <-1) represented only $14 \%$ or 14 years for this zone over 107 years of rainfall data. However, the same analysis by period shows that during the first period (1914-1949) the climate of the "Favorable Rain-fed" zone was characterized by a high number of wet-very wet years and fewer dry years without any registered very dry or extremely dry years, while during the following period (1950-1990), there were almost as many wet to extremely wet years as dry years to extremely dry years. But during the last three decades, there have been 6 times more dry years than wet years with more frequent and severe droughts (SPI < -2) (Table 1; Fig. 2). 


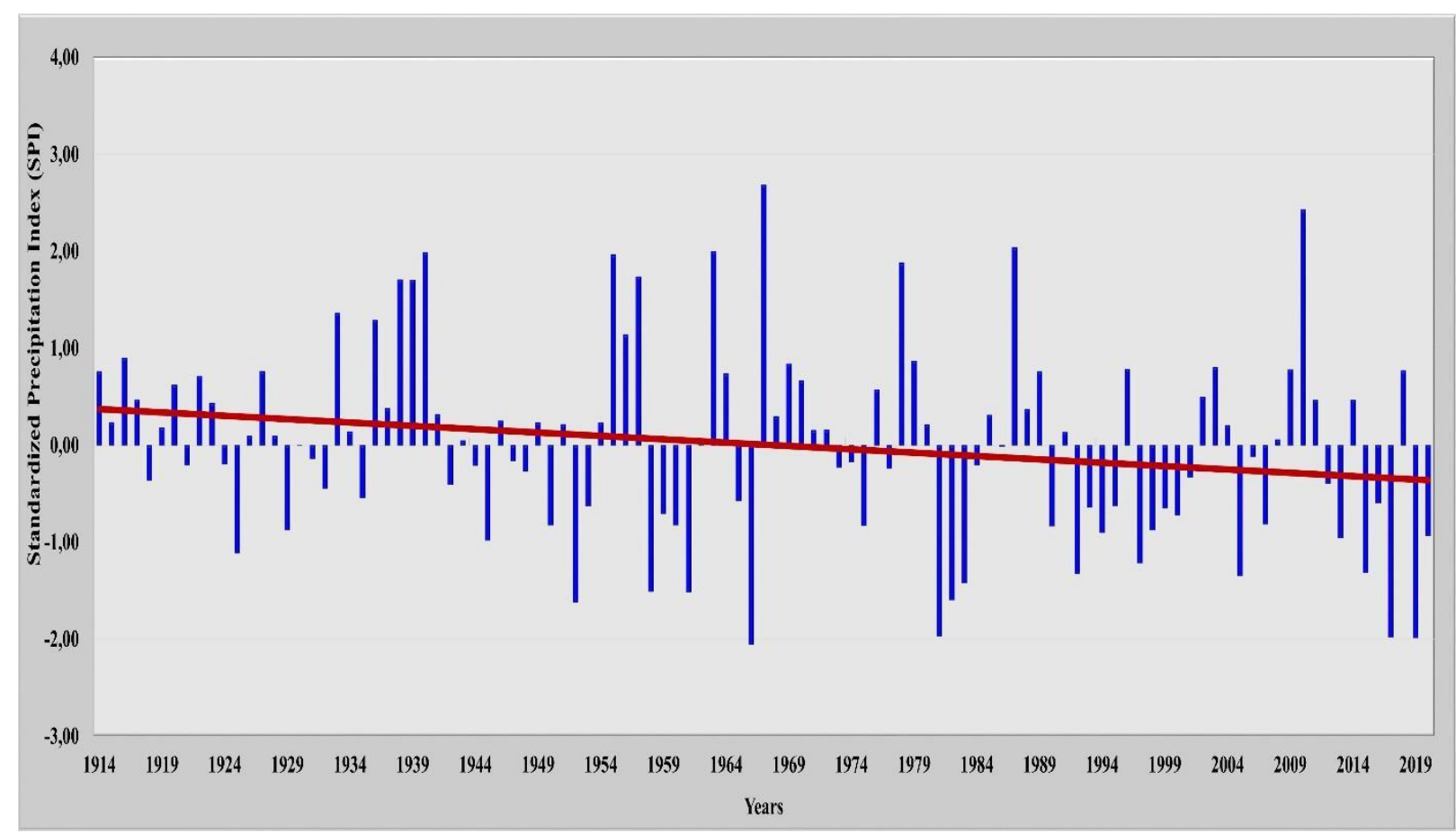

Figure 2: Evolution of the Standardized Precipitation Index (SPI) during the period 1914-2020 in the agro-climatic "Favorable Rain-fed" zone of Settat Province, Morocco.

Table 1: Standardized Precipitation Index (SPI) values by climatic category (McKee et al., 1993) for the "Favorable Rain-fed" zone of Settat Province.

\begin{tabular}{|c|c|c|c|c|c|}
\hline \multirow[t]{2}{*}{ SPI values } & \multirow{2}{*}{$\begin{array}{l}\text { Categories } \\
\text { (McKee et al., } \\
\text { 1993) }\end{array}$} & \multicolumn{3}{|c|}{ Years per period } & \multirow[t]{2}{*}{ Total } \\
\hline & & 1914-1949 & 1950-1990 & 1991-2020 & \\
\hline $\begin{array}{l}2,0<\text { more } \\
\text { than }\end{array}$ & Extremely humid & 0 & 3 & 1 & 4 \\
\hline 1,5 to 1,99 & Very humid & 3 & 3 & 0 & 6 \\
\hline 1,0 to 1,49 & Moderately humid & 11 & 1 & 0 & 12 \\
\hline $\begin{array}{l}-0,99 \text { to } \\
0,99\end{array}$ & close to normal & 21 & 27 & 23 & 71 \\
\hline$-1,0$ to $-1,49$ & Moderately dry & 1 & 1 & 4 & 6 \\
\hline$-1,5$ to $-1,99$ & Very dry & 0 & 5 & 1 & 6 \\
\hline les than $<-2$ & Extremely dry & 0 & 1 & 1 & 2 \\
\hline
\end{tabular}




\section{"Intermediate Rain-fed" Agro-climatic zone or "Guisser Zone"}

The SPI values on the same rainfall series for the 'Intermediate Rain-fed' zone show again the high variability of the rainfall with a downward trend in this index but less nuanced than for the "Favorable Rain-fed" zone (Fig. 2). At the start of this rainfall series, the SPI was slightly positive with few dry years while towards its end, it turned negative indicating the high dry years' frequency in this area.

The overall analysis shows that the majority of years (73 years or 68\%) had indices close to normal $(-0.99<$ SPI < 0.99) (Table 1$)$. Moderately humid to extremely humid years $(1<\mathrm{SPI}<$ +2 ) represented $17 \%$ or 18 years over the entire time series, while moderately dry to extremely dry years $(-2<$ SPI $<-1)$ represented $15 \%$ or 15 years. It should be noted at this level that the number of favorable years and the dry years were relatively similar for the zone. However, the analysis by period for the "Intermediate Rain-fed" zone shows that the first period (1914-1949) was characterized by a high number of normal years ( 29 years) and a few ( 5 years) wet to very wet years, and low number ( 2 years) of moderately dry to very dry years without any extremely dry year, while during the following period (1950-1990), there were less normal years (22 years instead of 29 years), more wet to extremely wet years (11 years with 2 extremely wet years instead of 5 years), and more dry to extremely dry years (8 years with 1 extremely -SPI $<-2$ year instead of 2 years). But during the last three decades, there have been 3 times more dry years than wet years and with more frequent and severe droughts (SPI $<-2)$, that is 6 dry to extremely dry years and only 2 wet years (Fig. 3; Table 2).

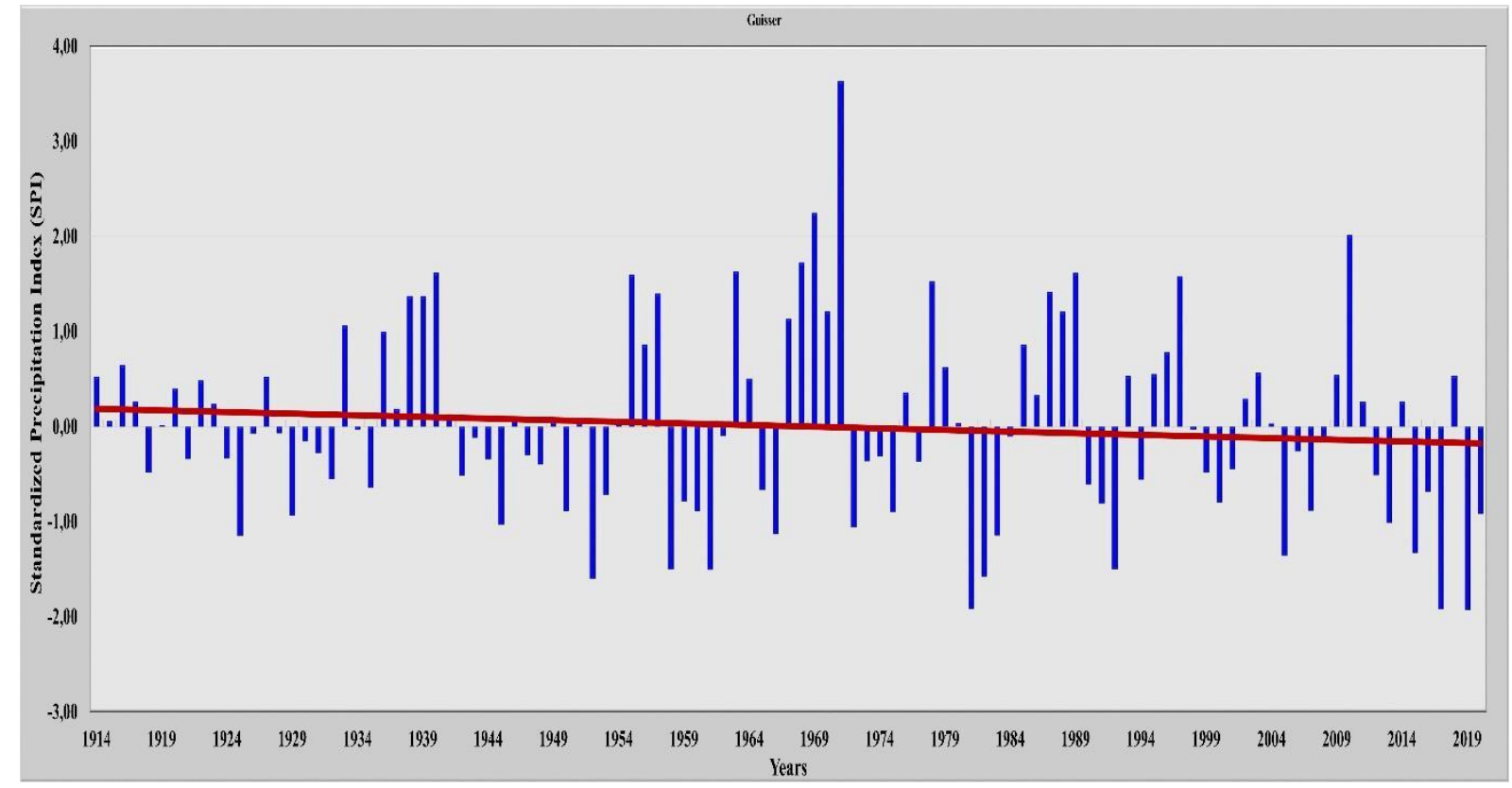

Figure 3: Evolution of the Standardized Precipitation Index (SPI) during the period 1914-2020 in the agro-climatic "Intermediate Rain-fed" zone of Settat Province, Morocco. 
Table 2: Standardized Precipitation Index (SPI) values by climatic year category (McKee et al., 1993) for the "Intermediate Rain-fed" zone of Settat Province.

\begin{tabular}{|c|c|c|c|c|c|}
\hline \multirow[t]{2}{*}{ SPI values } & \multirow{2}{*}{$\begin{array}{c}\text { Categories } \\
\text { (McKee et al., } \\
\text { 1993) }\end{array}$} & \multicolumn{3}{|c|}{ Years per period } & \multirow[t]{2}{*}{ Total } \\
\hline & & 1914-1949 & $\begin{array}{l}1950- \\
1990\end{array}$ & $\begin{array}{l}1991- \\
2020\end{array}$ & \\
\hline $\begin{array}{l}2,0<\text { more } \\
\text { than }\end{array}$ & Extremely humid & 0 & 2 & 1 & 3 \\
\hline 1,5 to 1,99 & Very humid & 1 & 4 & 1 & 6 \\
\hline 1,0 to 1,49 & Moderately humid & 4 & 5 & 0 & 9 \\
\hline $\begin{array}{l}-0,99 \text { to } \\
0,99\end{array}$ & Close to normal & 29 & 22 & 22 & 73 \\
\hline$-1,0$ to $-1,49$ & Moderately dry & 2 & 3 & 3 & 8 \\
\hline$-1,5$ to $-1,99$ & Very dry & 0 & 4 & 1 & 5 \\
\hline les than $<-2$ & Extremely dry & 0 & 1 & 2 & 3 \\
\hline
\end{tabular}

\section{"Less Favorable Rain-fed" Agro-climatic Zone or "El Brouj Zone"}

The SPI values for the "Less Favorable Rain-fed" zone show great variability over time but without any changes of the average value. Unlike the previous agro-climatic zones, this index remains low and stable over time, which confirms the aridity of this zone that experiences very frequent and quite severe droughts (Fig. 3).

The overall analysis shows that the majority of years (74 years or 69\%) had indices close to normal $(-0.99<$ SPI < 0.99). Moderately humid to extremely humid years $(1<$ SPI $<+2)$ represented $17 \%$ or 18 years over the entire time series, while the moderately dry to extremely dry years $(-2<$ SPI $<-1)$ represented $14 \%$ or 15 years (Table 3$)$. The overall number of favorable years was slightly higher than that of dry years (18 versus 15 years) in this area. However, the analysis by period shows that the distribution of wet years and dry years changed from one period to another. In fact, during the first period (1914-1949), 28 years were normal, 5 years were humid to very humid, and only 3 years were moderately dry, while during the following period (1950-1990), there were 30 normal years, 6 wet to extremely wet years, and 5 dry to extremely dry years. But in the last three decades, there have been only 16 normal years, 7 wet to extremely wet years, and 7 dry to extremely dry years. We also note that during the last period, the droughts became extreme (Fig. 3; Table 3). 


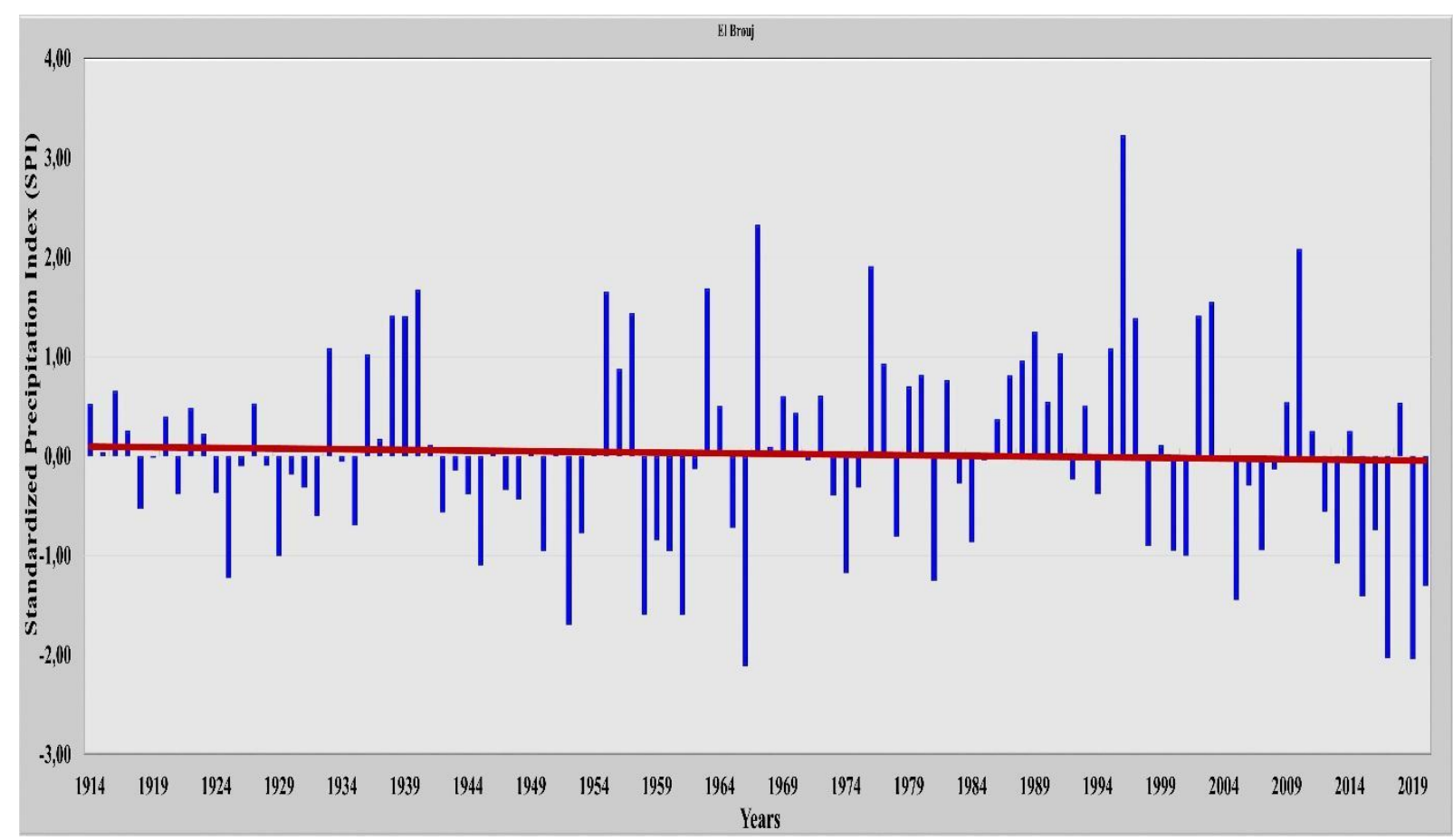

Figure 4: Evolution of the Standardized Precipitation Index (SPI) during the period 1914-2020 in the agro-climatic "Less Favorable Rain-fed" zone of Settat Province, Morocco.

Table 3: Standardized Precipitation Index (SPI) values by climatic year category (McKee et al., 1993) for the "Less Favorable Rain-fed" zone of Settat Province.

\begin{tabular}{|c|c|c|c|c|c|}
\hline \multirow[t]{2}{*}{ SPI values } & \multirow{2}{*}{$\begin{array}{c}\text { Categories } \\
\text { (McKee et al., } \\
\text { 1993) }\end{array}$} & \multicolumn{3}{|c|}{ Years per period } & \multirow[t]{2}{*}{ Total } \\
\hline & & 1914-1949 & $1950-1990$ & $\begin{array}{l}1991- \\
2020\end{array}$ & \\
\hline $\begin{array}{l}2,0<\text { more } \\
\text { than }\end{array}$ & Extremely humid & 0 & 1 & 2 & 3 \\
\hline 1,5 to 1,99 & Very humid & 1 & 4 & 1 & 6 \\
\hline 1,0 to 1,49 & Moderately humid & 4 & 1 & 4 & 9 \\
\hline $\begin{array}{l}-0,99 \text { to } \\
0,99\end{array}$ & Close to normal & 28 & 30 & 16 & 74 \\
\hline$-1,0$ to $-1,49$ & Moderately dry & 3 & 2 & 5 & 10 \\
\hline$-1,5$ to $-1,99$ & Very dry & 0 & 2 & 0 & 2 \\
\hline les than $<-2$ & Extremely dry & 0 & 1 & 2 & 3 \\
\hline
\end{tabular}




\section{DISCUSSION}

According to the obtained results on the characterization of the climate using the SPI across the different agro-climatic zones of Settat Province over the period 1914-2020, we notice that the number of normal years decreased over time in the three agro-climatic zones. These results confirm those reported by Sebbar et al. (2011) in the central area of Morocco that covered our study area.

The SPI values evolved over 107 years varied between the agro-climatic zones. The more we move from the "Favorable Rain-fed" zone towards the "Intermediate Rain-fed" zone and the "Less Favorable" zone, the more the SPI values stabilize, approaching the values of normal years. These SPI trends indicate that the aridity that was normal in arid areas like El Brouj migrated to the north and north-west towards the Favorable areas of Settat Province. Some investigators reported that this trend took place in many areas of Morocco since 1970's (El Ouali et al., 2008; Driouech et al., 2009b) while others found that it was clearly established since the 1980's (Ait Bella \& Samih, 2020; Alahiane, 2018).

Droughts not only became more frequent in the three agro-climatic zones of Settat Province, but their severity increased with SPI values approaching -2 or less. These results, that confirm those reported by many authors (Benaouda and El Mzouri, 2013; El Ouali et al., 2008; Sebbar et al., 2013; Mokssit, 2012; Alahiane, 2020), invite us to consider the permanent nature of aridity that is taking place in the majority of Moroccan agro-climatic zones and particularly those of Chaouia cereal producing plains where Settat is part of. The work carried out in the Chaouia by several investigators (Ait Bella \& Samih, 2020; Sebbar, 2013; El Ouali, 2010) showed that the SPI recorded its lowest value (-2.54) in 1983, and its highest (+1.99) in 1996. They indicated a clear upward trend in the SPI between October and December (planting period) and a downward trend between January and March, a critical period for growth and the development of cultures.

\section{Implication to Research and Practice}

The findings that demonstrate the migration of aridity towards the North on a local scale basis (Provincial scale) confirm those reported on large scales (regional and national). Through the aridity concept, permanent water deficit is expanding and becoming the normal climatic behavior touching, therefore, more agricultural areas and more farming communities. Research on drought characterization will provide strategic orientation for a better mitigation and adaptation of rural populations.

\section{CONCLUSION}

The analysis of climatic data from the Province of Settat over a series of more than a century (1914-2020) highlights the climate spatial and temporal variability within a small-scale territory such as Settat Province. The climate of the various agro-climatic zones studied within the province is characterized by more rainfall scarcity and variability, an increasingly high frequency of dry years and drought severity at the local level of the three agro-climatic zones. Even though results show that normal (average) years are declining, dry years are increasing and wet or humid years are declining in the three zones, the SPI changes over time is not similar for the three zones, that is, the rainfall deficit is taking place more in the "Favorable Rain-fed" 
zone and to a less degree in the "Intermediate Rain-fed" zone but not in the "Less Favorable" zone.

\section{Future Research}

In addition to drought characterization, research is needed on seasonal water deficits and on the length of the growing periods to better adapt the management of the existing upcoming cropping systems.

\section{REFERENCES}

Agoumi, A. \& Debbarh, A. (2006). Ressources en eau et bassins versants du Maroc : 50 ans de développement (1955-2000). 62 pp. http://www.rdh50.ma/fr/pdf/contributions/GT81.pdf.

Ait Bella, A. \& Samih, A. (2020). Caractérisation de la sècheresse climatique sur l'axe CasaSettat. PFE. Master Gestion de l'Environnement et Développement Durable. Faculté des sciences Ben M'Sik. Université Hassan II. Casablanca. 19 pages.

Alahiane, K. (2020). Impact du changement climatique sur les systèmes de cultures et mécanismes d'adaptation dans la plaine de Abda-Ahmar. Mémoire de thèse de Doctorat. Présenté pour obtenir le diplôme de Doctorat National Formation Doctorale : Biologie, Santé et Environnement Spécialité : Agronomie/Biologie.Centre d'Etudes Doctorales Sciences et Techniques. FST Settat. Université Hassan $1^{\mathrm{er}} .275$ pages

Alahiane, K., El Mzouri, E., Maadid, H., El Hani, S. \& Koulali, Y. (2018). Drought characterization in Ahmar dryland area of Morocco. International Journal of Scientific \& Engineering Research Volume 9, Issue 4, pp 1296-1299.

Benaouda, H., \& El Mzouri, E. (2013). Climate Variability, Wheat production and quality, and Decision making tools under Dry Farming. Dry land agricultural research in Morocco achievements and perspectives. Atelier « Drought Early Warning System and Adaptation Technology in the Drought Region of Africa China-UNEP-Africa Water Action". Safi le 8-12 avril, 2013. 12 pages. INRA CRRA de Settat.

Born, K., Fink, A. \& Paeth, H. (2008). Dry and wet periods in the northwestern Maghreb for present day and future climate conditions. Meterologische Zeitschrift 17, 533-551.

Boubekri, A., Saloui, A., Kanjaa, R. \&. Filali, A. (2019). Les changements climatiques au Maroc : outils et réflexions. In ' le changement climatique, la variabilité et les risques climatique'. XXXII ème Colloque Internationale de l'AIC. Thessaloniki - Grèce 29 mai au 1 juin 2019. Pages: 15-20. Site web du colloque: https://aic2019auth.org/.

Driouech, F. (2009a). Le changement climatique : Problématique mondiale/Réponse mondiale. Actes de la rencontre Internationale sur le Changement Climatique : Enjeux et Perspectives d'adaptation pour le Maroc, organisée par l'Institut Royale des Etudes Stratégiques (IRES), Rabat le 16 octobre 2009.

Driouech, F. (2009b). Variabilité et changements climatiques au Maroc : Observations et projections.(EC/CNRM, Direction de la Météorologie Nationale). Conférence nationale : les changements climatiques au Maroc : défis et opportunités. Rabat, 11-12 février 2009. 
Driouech, F., Mahé, G., Déqué, M., Dieulin, C., El Heirech, T., Milano, M.E., \& Rouche, N. (2010). Evaluation d'impacts potentiels de changements climatiques sur l'hydrologie du bassin versant de la Moulouya au Maroc. Global Change: Facing Risks and Threats to Water Resources, 561-567.

El Jihad, M. D., Peyrusaubes, D., \& El Bouzidi, A. (2014). Sécheresses saisonnières et changement climatique dans le Gharb (Maroc). Rur@lités. 2014. Le Gharb, un territoire à l'épreuve du changement climatique. Coordination : Moulay-Driss EL JIHAD et Daniel PEYRUSAUBES Revue électronique du laboratoire de Géographie «RURALITES » de l'Université de Poitiers, (Numéro 4 - année 2014) pp. 14-25. hal01185293.

El Ouali, A. (2010). Etude vulnérabilité et adaptation du Maroc face aux changements climatiques, p. 8-9.

El Ouali, E., Benaouda, H., El Mzouri, E., Chriyaa, A., \& Saloui, A. (2008). Rapport annuel du projet INRA-IDRC, Mécanismes d'adaptation aux changements climatiques des Communautés rurales dans deux écosystèmes contrastés de plaine et de montagne du Maroc, INRA Maroc.

Emberger, L. (1933). Nouvelle contribution à l'étude de la classification des groupements végétaux. Rev. Gen. Bot. 45: 473-486.

IPCC. (2013). Climate Change 2013: The Physical Science Basis. Contribution of Working Group I to the Fifth Assessment Report of the Intergovern- mental Panel on Climate Change. Cambridge University Press, Cambridge, United Kingdom and New York, NY, USA. 1535 p.

Jacobi, J. \& Perrone, D. (2013). A tool for calculating the Palmer drought indices. Water Resources Research, 49 (9), 6086-6089.

Jones, H.G. (1992). Drought and drought tolerance. Cambridge University Press, UK. Joshi.

MCKee, T.B., Doesken, N.J., \& Kleist, J. (1993). The relationship of drought frequency and duration to time scales, Proceedings of the 8th Conference on Applied Climatology, 1722 January 1993, Anaheim, California, 179-184.

Meddi, H. \& Meddi, M. (2009) : Variabilité des précipitations annuelles du Nord-Ouest de l’Algérie. Sécheresse, 20(1), 57-65.

Mirabbasi, R., Anagnostoub, E.N., fakheri-farda, A., Dinpashoha, Y., \& Eslamianc, S. (2013). Analysis of meteorological drought in northwest Iran using the Joint Deficit Index. Journal of Hydrology, (492), 35-48.

Mokssit, A. (2012). «L'état du changement climatique et ses impacts au Maroc : le point sur le changement climatique au Maroc », in Environnement et changement climatique au Maroc : diagnostic et perspectives, Ed. Zeino-Mahmalat E. et Bennis A., KonradAdenauer-Stiftung e.V., Bureau au Maroc, pp. 36-39.

OMM. (2009). Déclaration de l'OMM sur l'état du climat mondial en 2009, 16 p.

Pashiardis, S. \& Michaelides, S. (2008). Implementation of the standardized precipitation index (SPI) and the reconnaissance drought index (RDI) for regional drought assessment: a case study for Cyprus. European Water 23/24, 57-65.

Sebbar, A., Fougrach, H., Hsaine, M., Saloui, A., \& Badri, W. (2011). Etude de la variabilité du régime pluviométrique au Maroc septentrional (1935-2004). Sécheresse, 22, 139-48.

Sebbar, A., Hsaine, M., Fougrach, H. \& Badri, W. (2012). Étude des variations climatiques de la région centre du Maroc. Conférence Paper · 25ème Colloque de 1'Association Internationale de Climatologie, Grenoble 2012. 709-714 
Sebbar, A., Hsaine, M., Fougrach, H. \& Badri, W. (2013). Carte des précipitations annuelles au Maroc (1935/2006). Actes du XXVI colloque de l'Association internationale de la Climatologie 475-480

Tirandaz, M. \& Eslami, A. (2012). Zoning droughts and wetness trends in north of Iran: A case study of Guilan province. African Journal of Agricultural Research, 7(15), 23202327.

Zamrane, Z. (2018). Recherche d'indices de variabilité climatique dans des séries hydroclmatiques au Maroc : identification, positionnement temporel, tendances et liens avec les fluctuations climatiques : cas des grands bassins de la Moulouya, du Sebou et du Tensift. Sciences de la Terre. Université Montpellier, ffNNT : 2016MONTT181ff. https://tel.archives-ouvertes.fr/tel-01690063

Zinyengere, N., Rochane, S., Joel, J., Mahenge, P., Matata, V. , Mwaifunga, G., Aichata, F. , Sako, M., \& Zebsa, M. (2015). Climate change and food security in Africa. Edited by Tracy Cull and Catherine Vincent. Africa Climate Change Fellowship Program (ACCFP) Institute of Resource Assessment University of Dar es Salaam P.O Box 35097 Dar es Salaam, Tanzania accfp@ira.udsm.ac.tz;accfp2@gmail.com:www.accfp.org. IDRC-Canada. 32 pages. 